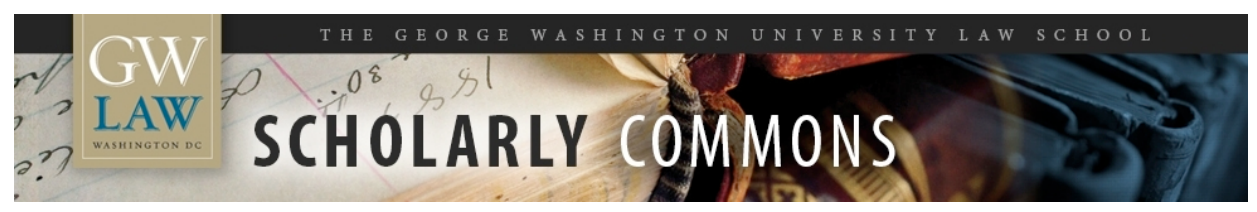

\title{
Why the International Exhibitions Bureau Should Choose Minneapolis for Global Expo 2023
}

Steve Charnovitz

George Washington University Law School, scharnovitz@law.gwu.edu

Follow this and additional works at: https://scholarship.law.gwu.edu/faculty_publications

Part of the Law Commons

\section{Recommended Citation}

Charnovitz, Steve, Why the International Exhibitions Bureau Should Choose Minneapolis for Global Expo 2023 (October 15, 2017). GWU Law School Public Law Research Paper No. 2017-82; GWU Legal Studies Research Paper No. 2017-82. Available at SSRN: https://ssrn.com/abstract=3053623

This Article is brought to you for free and open access by the Faculty Scholarship at Scholarly Commons. It has been accepted for inclusion in GW Law Faculty Publications \& Other Works by an authorized administrator of Scholarly Commons. For more information, please contact spagel@law.gwu.edu. 


\title{
Why the International Exhibitions Bureau Should Choose Minneapolis for Global Expo 2023
}

\author{
Steve Charnovitz*
}

Next month in mid-November 2017, the International Exhibitions Bureau (BIE) will award one country the opportunity to host a specialized global expo in the years 2022-23. Of the three contenders, the United States (U.S.) proposal to hold an Expo in Minneapolis, Minnesota merits selection over the two other alternatives of Poland and Argentina. The proposed theme of the Minneapolis fair of "Healthy People, Healthy Planet" is a well-chosen topic to draw and educate participants from around the world.

The BIE originated in the Convention Relating to International Exhibitions of 1928 (done in Paris). ${ }^{1}$ The early 20 th century was a time of formation of many international organizations, and the Convention set up a regulatory system for world's fairs and expos to supervise the conduct and selection of international exhibitions. The Convention of 1928 is an especially interesting international regime that included international customs regulations and provided for the advisory participation of the International Chamber of Commerce in the BIE's Administrative Council. ${ }^{2}$ After World War II, the BIE skipped any effort to affiliate as a specialized agency of the United Nations.

\footnotetext{
*Professor Charnovitz teaches at George Washington University Law School, Washington, DC, USA.

${ }^{1}$ Nov. 22, 1928, 111 LNTS 343. An earlier Berlin Conference of 1912 had discussed the need for supervision, but that diplomatic conference did not reach a solution.

${ }^{2} / d$. Arts. 11, 18-25. Among the exposition-related trade disciplines were providing temporary duty-free treatment, protection of geographic indications, regulation of monopolies, and providing national treatment for rates of labor.
} 
True world's Fairs had begun in 1851 with Great Exhibition of London (opened by Queen Victoria), and by the late 19th century they were being held with considerable frequency and publicity. The fairs often provided opportunities to demonstrate new technology and to promote cultural diversity and were a celebration of futurism. In some cases, the fairs also boosted global governance. For example, at the Universal Exposition of Paris in 1878, the French government organized an international congress on industrial property that started the process of achieving the first international treaty on intellectual property. ${ }^{3}$

The United States was not an early sponsor or member of the $\mathrm{BIE},{ }^{4}$ and joining the $\mathrm{BIE}$ did not occur until May 1968 after President Lyndon B. Johnson recommended US Senate approval, and the Senate did so without any dissenting votes. ${ }^{5}$ In recommending that the United States ratify the Convention, Under Secretary of State Nicholas deB. Katzenbach explained that "The basic purpose of the convention and the BIE is to prevent a state of anarchy in the holding of international expositions...."6

In 1988, the BIE General Assembly approved a set of amendments to revise the system of the international selection of exhibitions by initiating a new distinction between the

\footnotetext{
3Steve Charnovitz, Two Centuries of Participation: NGOs and International Governance (1997), reprinted in, Charnovitz, TRAde LAW AND Global GovernanCE (Cameron May 2002), at 397, 413.

${ }^{4}$ See http://www.nywf64.com/intpar03.shtml and 90th Cong. 2nd Session, Senate Executive Report No. 2, at 1-2. Among the original parties to the 1928 treaty were several countries in the Americas including, for example, Haiti, Peru, Brazil, and Canada.

${ }^{5}$ Cong. Rec. Senate, Nov. 28, 1967, 33907-08; Cong. Rec. Senate, Apr. 30, 1968, 11004-11009; Cong. Rec. Senate, Apr. 30, 1968, 11012.

6International Exhibitions Convention, with Protocols, Message from the President of the United States, 90th Cong. 1st Sess., Executive P, 1967, at 3.
} 
"registered exposition" held at five year intervals and the shorter and smaller "recognized exposition" held in a time period between registered expositions. ${ }^{7}$ The United States was one of the parties that worked the hardest within the BIE for the adoption of these amendments, and in 1990 the US Department of State sought Senate approval of the 1988 amendments. ${ }^{8}$ The Senate approved the ratification of the 1988 amendments in August 1991.

Within several years, Senate and House support for the BIE waned. In 1998, the Congress stopped appropriating funds for the BIE and the State Department appropriators urged US withdrawal from the BIE and denunciation of the treaty. ${ }^{9}$ In parallel, the Clinton Administration failed to offer any effective defense of the BIE.

When the George W. Bush Administration came into office, US withdrawal from the 1928 Paris Convention became one of the Administration's early foreign policy accomplishments. In April 2001, the Bush Administration gave a one-year notice of withdrawal from the BIE. This withdrawal was effectuated by a letter from US Secretary of State Colin L. Powell to the Minister of Foreign Affairs of France, France being the depositary nation for the treaty. The United States is not the only country to quit the BIE. For example, in recent years,

\footnotetext{
${ }^{7}$ Amendments to the 1928 Convention Concerning International Expositions, As Amended, Message from the President of the United States, Senate Treaty Doc. 101-15, March 20, 1990, at v-vii.

${ }^{8}$ US Senate Committee on Foreign Relations, Four Treaties, Hrg. 102-248, July 18, 1991, at 6, 89.

${ }^{9}$ Circular 175 Request, Memo from IO David Welch to The Secretary of State, Apr. 9, 2001. See also Toumil Reza Samonte Allen, "Opening the X-Files: A Case for Rejoining the Bureau International des Expositions (BIE)", April 2015, at 9-10, available at https://dukespace.lib.duke.edu/dspace/bitstream/handle/10161/9708/Opening\%20the\%20XFiles-\%20A\%20Case\%20for\%20Rejoining\%20the\%20BIE.pdf\%3Bsequence=1.
} 
both Australia and Canada have quit, and neither country is currently a member state of the Convention.

The movement to bring the United States back into the BIE began in 2014 and jumped into full swing in early 2017. The speed with which the key Congressional and Executive Branch actions were taken on a bipartisan basis is a remarkable achievement in a year of lawmaking frustration, hyper-partisanship, and inter-branch tension.

Legislation was introduced into the U.S. House of Representatives on January 13, 2017 by Republican Congressman Tom Emmer and was passed on a voice vote on April 25. The bill was titled "U.S. Wants to Compete for a World Expo Act."10 This bill was slightly amended by the Senate and then approved by unanimous consent on May 4. The Senate-passed bill was quickly returned to the House on the same day and given final approval. By May 8, 2017 President Donald J. Trump had signed the bill into law as Public No. $115-32 .{ }^{11}$

The new law authorizes the US Secretary of State to "take such actions as the Secretary determines necessary for the United States to rejoin and maintain membership in the BIE." 12 On the day after the bill became law, US Secretary of State Rex W. Tillerson approved accession of the United States to the Convention subject to two reservations, one opting out the binding

\footnotetext{
${ }^{10 H . R . ~} 534$.

${ }^{11}$ Bill Chappell, "President Trump Signs Bipartisan Bill for U.S. To Rejoin World's Fair Group," National Public Radio, May 9, 2017, available at http://www.npr.org/sections/thetwoway/2017/05/09/527624700/president-trump-signs-bipartisan-bill-for-u-s-to-rejoin-worlds-fairgroup. 22 USC $\$ 2425$ b note, 131 Stat. 843.

${ }^{12} / d . \S 4(\mathrm{a})$.
} 
arbitration offered in the Convention and the other clarifying that while it could not guarantee that private expo organizers fulfill certain obligations in the Convention, that the US government would make "every reasonable effort to ensure" private organizers ensure fulfillment of their obligations under the Convention. ${ }^{13}$

On May 10, 2017, the Convention went into force for the United States and the United States became the BIE's 170th member. ${ }^{14}$ The lack of Senate advice and consent reflects an apparent agreement by the Senate and President Trump that no separate Senate approval was needed under the Constitution's Art. II treaty ratification process. The Convention should thereby be classified as a treaty entered into as an ex post Congressional-Executive Agreement.

The BIE is currently headed by Secretary General Vicente Gonzalez Loscertales, a highlyregarded Spanish diplomat who oversees the competition process for hosting the recognized specialized expo of $2022 / 23$. The decision is not made by the BIE itself, but rather by its General Assembly which consists of the governments of the contracting parties. The vote to elect the host government is taken by a majority vote of the member countries. ${ }^{15}$ According to the BIE website, the vote is taken on a secret ballot. ${ }^{16}$

\footnotetext{
${ }^{13}$ US Department of State, Accession on Behalf of the United States of America, May 9, 2017.

${ }^{14}$ See http://www.bie-paris.org/site/en/news/87-news-announcements/bie-activity/1335-theunited-states-becomes-the-170th-member-state-of-the-bie. The current Convention is published as TIAS 17-510. The trade rules in the Convention are now re-codified as amended into a Customs Regulations Annex referenced in Art. 16.
}

${ }^{15}$ TIAS 17-510, Art. 28.3.

${ }^{16}$ See http://www.bie-paris.org/site/en/faqs/118-questions-on-expos. 
As noted above, the current Convention provides for two types of international exhibitions, the "registered" expo and the "recognized" expo. ${ }^{17}$ The United States is currently competing for the $2022 / 23$ recognized exhibition. The terms of the Convention state that a recognized exhibition "must illustrate a definite theme." 18 This requirement was put into place in the treaty amendments of 1988. In its public communications, the BIE has adopted more reader-friendly and descriptive categories. For example, the BIE makes a distinction between World Expos and Specialized Expos (rather than Registered and Recognized) and explains that the latter ... "are global events dedicated to finding solutions to precise challenges of humanity...." 19 In addition, the BIE website notes that "the BIE issued a resolution in 1994 that stated Expos must address crucial problems of our time and tackle the challenge of environmental protection."20 The BIE website further explains:

${ }^{17}$ In 1991 testimony to the US Senate Committee on Foreign Relations, the Assistant Legal Adviser for Treaty Affairs explained one of the purposes of the treaty amendment was to "Eliminate a defunct distinction between the 'special' and 'universal' category of expositions...." US Senate Committee on Foreign Relations, Four Treaties, Hrg. 102-248, July 18, 1991, at 9. This explanation is confirmed by the BIE website which explains that the 1988 amendment (which entered into force in 1996) re-designated the universal exhibition as a registered exhibition and re-designated the specialized exhibition as the recognized exhibition. See http://www.bieparis.org/site/en/faqs/118-questions-on-expos.

${ }^{18}$ TIAS 17-510, Art. 4(A)2.

${ }^{19}$ See http://www.bie-paris.org/site/en/expos/about-expos/expo-categories/internationalspecialized-expos.

${ }^{20}$ See http://www.bie-paris.org/site/en/bie/our-history. 
The selection criteria are based on the feasibility and the viability of the Expo project as determined by the Enquiry Mission, as well as the appeal of the proposed Expo theme and whether it allows for the participation of each country in the Expo. Member States also take into consideration their bilateral relations with the candidate countries when considering their vote. ${ }^{21}$

\section{Analyzing the Current Competition}

Three government bids are now being vetted by the $\mathrm{BIE}^{22}$ : Poland is proposing an expo starting in June 2022 with the theme "City Re:Invented."23 The expo would be held in Lódz, a city in central Poland. Poland has never hosted a specialized expo. Argentina is proposing an expo starting in January 2023 with the theme "Science, Innovation, Art and Creativity for Human Development." 24 The expo would be held in Buenos Aires. Argentina has never hosted a BIE-recognized expo, but Buenos Aires did host the Centennial International Exposition of 1910. The United States is proposing an expo starting in May 2023 with the theme "Healthy People, Healthy Planet." The expo would be held in Minneapolis Minnesota. ${ }^{25}$ The United States has hosted ten expos (beginning in 1876), but none in Minnesota. The closest expo to Minneapolis (408 miles) was the Chicago Century of Progress World's Fair of 1933.

\footnotetext{
${ }^{21}$ See http://www.bie-paris.org/site/en/expo-candidature-en/specialised-expo-2022-23/165bidding-process.

${ }^{22}$ See http://www.bie-paris.org/site/en/news/87-news-announcements/bie-activity/1241-listof-candidates-for-specialised-expo-2022-23.

${ }^{23}$ See http://expo2022.uml.lodz.pl/index_en.html.

${ }^{24}$ See http://en.expo2023argentina.com/theme/.

${ }^{25}$ See http://expo2023.info.
} 
Given the remoteness of the Polish expo site, the competition is widely expected to be a choice between Buenos Aires and Minneapolis. Both are world class cities and exciting places to visit. Although the Argentina economy suffered under bad economic policies for many years, a change in government has led to an improving economy. ${ }^{26}$ The US economy remains strong under a new national government with weak approval ratings.

From a legal perspective, the US proposal would be the better choice because the Argentina proposal lacks the "definite theme" required by the treaty. ${ }^{27}$ Moreover, the Argentina proposals fails the BIE guidance of an expo that proposes "solutions to precise challenges of humanity." ${ }^{28}$ Argentina's broad topics of science, innovation, art, and creativity are clearly important, but they hardly constitute a definite theme. By contrast, the US proposal has a sharper focus of healthy people on a healthy planet. While the quest to safeguard public health is a precise challenge of humanity that will draw upon science, innovation and creativity, the characterization of science itself as a precise challenge of humanity seems inapposite.

Thus, if the treaty rules are to be followed, the BIE Assembly should award the next specialized expo to the United States.

Of course, any vote by governments is political and so the poor fit of the Argentina theme to the treaty requirements will be just one basis for the forthcoming decision. Equity considerations might weigh in favor of Argentina since there have been relatively fewer expos

\footnotetext{
${ }^{26}$ See http://www.heritage.org/index/country/argentina.

${ }^{27}$ See text accompanying above note 18 . The value of a definite theme is to improve the takeaway educational value-added from attending an expo.
}

${ }^{28}$ See text accompanying above note 19. 
in the Southern hemisphere. In addition, BIE members might rightly ask whether they should reward the United States for rejoining the BIE opportunistically to further the US bid for the expo. Indeed, the US Congress unabashedly chose the title of "U.S. Wants to Compete for a World Expo Act" for its new law catalyzing the US re-entry into the BIE. ${ }^{29}$

Nevertheless, the BIE delegates should not hold against the United States the competitive aspects of the US re-accession. The United States might have rejoined the BIE for reasons that were not fully altruistic, but this is not a case where the United States did the right thing for the wrong reason. The urge to host a global fair is precisely the right reason to rejoin the BIE.

World expos have always been important events marking and furthering international cooperation and progress and the United States should always be part of that movement. Whether or not the United States wins this competition will not in the long run make that much difference for the United States. But having the United States back in the BIE will inevitably strengthen the BIE. Furthermore, the BIE's selection of the United States will solidify the new US membership in the BIE and reinforce US interest in international social and economic cooperation.

\footnotetext{
${ }^{29}$ The United States could have competed for the 2023 expo as a BIE non-party, but the required vote would have been two-thirds rather than a majority. TIAS 17-150, Arts. 7.2, 28.3(e).
} 
The recent announcement by the Trump Administration that the United States will withdraw from UNESCO ${ }^{30}$ shows the anti-internationalist influences on US foreign policymaking. To be sure, rejoining the BIE hardly makes up for what the United States and the world loses when the United States exited the Paris Agreement on Climate or exits UNESCO. But rejoining the BIE is important symbolically in showing that quitting an international organization is not irreversible. In any event, Minneapolis would be a great host for a successful world expo, and the BIE governments should seize this opportunity next month.

${ }^{30}$ Gardiner Harris \& Stephen Erlanger, "U.S. Will Withdraw From Unesco, Citing Its 'Anti-Israel Bias'", NEW YORK TIMES, Oct. 12, 2017, available at https://www.nytimes.com/2017/10/12/us/politics/trump-unesco-withdrawal.html. The United States had previously quit UNESCO in 1984 and then rejoined in 2002. 